\title{
Franchising and Entrepreneurship: High Reward or High Risk?
}

\author{
Gad J. Selig
}

According to the Department of Commerce, start-up, small, and family businesses are among the fastestgrowing areas of employment. Even under the best economic environment, starting a business is risky. To reduce the risks and to establish their own businesses, an increasing number of entrepreneurs and corporate converts are buying franchises.

Franchising has enjoyed a major increase in popularity during the early 1990 s, fueled largely by the growing pool of available candidates made possible by significant corporate and government downsizing. According to the Department of Commerce, franchising accounts for nearly one-third of all U.S. retail sales and employs over 7 million people.

If an individual has the motivation, skills, capital, leadership, entrepreneurial spirit, and risk-taking attributes required to start and manage a business, franchising provides a structured alternative to accomplish this objective. Franchising encompasses both high risks and high rewards. While it is not for everyone, franchising represents a method to start and/or transition into your own business.

This article describes the why, what, and how of franchising. It discusses the driving forces for franchising from both the franchiser's and franchisee's perspective, what it takes to be a franchisee, how to become an educated businessperson, what to do once you have selected a franchise, the do's and don'ts, the risks and rewards, and how to sell a franchise.

$\mathrm{R}$ estructuring of the workforce, corporate downsizing, and drastic cuts in defense and public-sector spending have caused significant worker displacement in the United States. According to the Department of Commerce, start-up, small, and family businesses are among the fastest-growing areas of employment. ${ }^{1}$

Franchising represents a significant component of this growth. An estimated 540,000 franchises employ over 7 million people, which accounts for $\$ 750$ billion in annual sales and a third of all retail sales. With socioeconomic changes continuing to create fertile ground for franchising, businesses are choosing to franchise with more individuals becoming franchisees. This article explores the why and how of franchising, the risks and rewards, and the do's and don'ts from both a conceptual and experiential basis.

\section{What Is and Why Franchise?}

In simple terms, "franchising" is a partnership between the franchiser and the franchisee. The franchiser contractually gives the franchisee the right to start and manage a franchise business according to certain rules and guidelines. The franchisee generally has the right, as an independent business owner, to manage and grow the business. As a franchisee, one has to pay dues (e.g., franchise fees, monthly royalties) which vary by franchise. These dues provide revenues necessary for the franchiser to operate and provide systems, training, marketing, promotion, and other services to all the franchise owners in the system.

According to the Department of Commerce, the following are some of the major reasons why companies decide to franchise.

- Franchising provides an effective method for raising capital to finance expansion.

- Franchising enables the franchiser to pool resources, advertise and promote, achieve economies of scale in purchases, expand internationally and develop new products and services.

- Franchising provides the franchiser quality control, consistency, and uniformity over goods and services produced and/or distributed as well as media, public relations, image and appearance.

- Franchising provides flexibility for responding to changing customer needs and emerging markets within a wide variety of sectors.

Individuals become franchisees for a number of reasons. 
- Individuals, who want to become business owners versus employees, are not comfortable doing it alone, but are comfortable working within a framework such as a franchise.

- Individuals want to pursue the American dream of achieving high rewards through risk sharing in a quasistructured environment.

- Individuals want the benefits of a franchiser's name recognition, network, systems, training, and infrastructure to help establish and grow their business.

- Individuals may be able to obtain financing more easily from a franchiser than from other sources.

- Franchising helps individuals transition from corporate life to ownership of their own business.

\section{Do You Have What It Takes to be a Franchisee?}

Based on my own experience, the most important characteristics of a franchisee are a strong work ethic and a highly motivated, winning attitude. As a franchisee, you will have to put considerable entrepreneurial drive to work to grow your business. You should be prepared to work hardest during start-up. You have to be ready to handle long days (twelve to sixteen hours) and perform multiple functions, including sales, marketing, purchasing, accounting, systems, human resources, and customer service. Franchises are more likely to succeed if their owners are actively involved in the day-to-day business management marketing, and operations in the initial stage.

According to Calvin Haskell, Jr., President of Franchise Solutions, a franchise advisory company, the best franchisees are those he refers to as "intrapreneurs." These people are driven by an entrepreneurial spirit to be profitable, yet also have the ability to work within a franchise system. The ideal is for people to be able to work within a structured environment. People who are too entrepreneurial just will not follow systems or guidelines of a franchisor. ${ }^{2}$

Exhibit 1 is a self-administered test, developed by Franchise Solutions, to help you determine if you have what it takes to be a franchisee $^{3}$

\section{How to Get Smart About Franchising?}

To decide if franchising is for you and to become an informed investor (since you will be investing anywhere from $\$ 25,000$ to several hundred thousand dollars), you must become educated in the franchising field. You need to understand the pros, cons, and risks of franchising.

There are two aspects to franchising: positive and negative. The positive aspects depict success and lucrative financial rewards for people like Ray Kroc (McDonald's), Colonel Sanders (KFC), and the thousands of millionaires they have helped into business. The negative aspects remind us of the early years of franchising when con artists sold empty promises of phony fast-food success as aired in a 60 Minutes TV report entitled, "From Burgers to Bankruptcy" in $1978 .{ }^{4}$ Understanding both sides of franchising is critical to selecting the right investment for your interests, competencies, skills, and resources. Here are some steps to help you become better informed and better educated.

- Read books, periodicals, and other surveys (e.g., Dun \& Bradstreet, Entrepreneur, Business Week) on franchising.

- Attend franchising trade shows and talk to franchisers in a variety of different products and service businesses. Obtain a copy of the Uniform Franchising Offering Circular (UFPC), a comprehensive disclosure prospectus made available to potential franchisees by franchisers you are reviewing. The UFOC contains much information about the franchiser, its key management group, fees to be paid (one time and recurring), the total estimated investment, key terms of the franchise agreement, the franchisors financials, addresses of current franchise owners, purchasing and other restrictions, a list of franchisees who have left the system, and other information. In addition, a copy of all contracts and agreements to be signed by the franchisee are available. After reviewing 


\section{Exhibit 1 \\ Self-test for Potential Franchisees}

1. You own a company. How much operation detail are you comfortable with?
a. I want direct control over all operations.
b. I delegate less than half.
c. I delegate more than half.

2. You have three job offers with comparable salary and benefits. Choose one.

a. Small company but high management responsibility and exposure.

b. Mid-sized company with less personal exposure but more prestigious name.

c. Large company with least personal exposure but very well-known name.

3. You reach a major stumbling block on a project. You:

a. Seek help from others immediately.

b. Think it through and then present possible solutions to your superior.

c. Keep working until you resolve it on your own.

4. Which investment sounds most appealing?

a. Five percent fixed return over a period of time.

b. From -20 to +50 percent loss or return over a period of time, depending on changing economic situations.

5. Which business arrangement is most appealing?

a. You're a sole owner.

b.You're in a partnership and own a majority of the stock.

c. You're in an equal partnership.

6. Your company's sales technique increases sales 10 percent per year. You used a technique elsewhere you feel will result in 15 to 20 percent annual increases, but it requires extra time and capital. You:

a. Avoid the risk and stay with the present plan.

b. Suggest your new method, showing previous results.

c. Privately use your system, and show the results later.

7. You suggest your system to your boss, and he says, "Don't rock the boat." You: a. Drop your different approach.

b. Approach your boss at a later time.

c. Go to your boss's boss with the suggestion.

d. Use your own system anyway.

8. Which would mean the most to you?

a. Becoming the president of a company.

b. Becoming the highest paid employee of a company.

c. Winning the highest award for achievement in your profession.

1. 9. What three activities do you find most appealing?

a. Sales and marketing

b. Administration

c. Payroll

d. Training

e. Customer service

f. Credit and collections

g. Management

10. What work pace do you generally prefer?

a. Working on one project until it is completed.

b. Working on several projects at one time.

Scoring:

1: $\mathrm{A}=5, \mathrm{~B}=3, \mathrm{C}=1$

2: $\mathrm{A}=3, \mathrm{~B}=2, \mathrm{C}=1$

3: $\mathrm{A}=1, \mathrm{~B}=5, \mathrm{C}=7$.

4: $A=2, B=6$.

5: $\mathrm{A}=7, \mathrm{~B}=5, \mathrm{C}=2$.

6: $\mathrm{A}=1, \mathrm{~B}=6, \mathrm{C}=10$.

7: $\mathrm{A}=1, \mathrm{~B}=5, \mathrm{C}=8, \mathrm{D}=10$.

8: $A=8, B=2, C=5$.

9: $A=10, B=1, C=3, D=3, E=8, F=2, G=5$.

10: $A=3, B=6$.

You would potentially be a good franchisee with a point-score range from 34 to 71 .

Range Comments

20-33 You're a corporate player, happiest in a structured environment.

34-71 You're a potentially good franchisee.

72-85 You're an entrepreneur, preferring total independence.

Source: Caffey, Andrew, "A Closer Look At Franchising," Entrepreneur, January 1996. 
these documents and talking to franchisees, the following questions should be addressed to the franchiser or its representative:

-What is the management philosophy and culture of the franchise? How do you view the franchisees?

-What are the franchiser's plans for expansion? New products and services? Alliances? New marketing and promotion programs? New systems? Field support? Training? National programs?

-Is there a dispute resolution mechanism in place between the franchiser and the franchisees? Arbitration?

-Is there a franchisee owners council? How does it operate? What role does it play in the franchiser's decisions?

-What are the primary reasons franchise owners succeed? Fail? Sell?

- Has the franchiser made any oral promises that are not reflected in the written franchise agreement?

-What are your renewal rights? What conditions must you meet to renew your agreement? Renewal fees?

- Under what terms or conditions are you allowed to terminate the franchise agreement? Sell your interests?

-Where franchisers claimed earnings (Item 19 of the UFOC), ask the franchiser to provide more specific earnings information about other franchisees in your potential market. The law allows a franchiser to provide such supplemental earnings information outside the UFOC. ${ }^{5}$

- Contact franchise and small business consultants, lawyers, CPAs, business brokers, and financial lending institutions to learn more about various kinds of businesses.

- Visit franchisees (both successful and unsuccessful; the latter will be more difficult to find) and ask these questions (similar questions should also be posed to franchise consultants, lawyers, CPAs, etc.):

-What were the gross sales over the last three years? What was your pretax net income? Is the franchise meeting your financial expectations? Nonfinancial expectations? Why? Why not?

-What is the most attractive part of the franchise? What is the least attractive part?

--If you had to do it over, would you still buy this franchise? Why? Why not?

- How would you evaluate the franchiser's pre-opening support programs such as training, location selection, grand-opening support, marketing assistance, operational support, etc.? How would you evaluate the post-opening support programs such as new marketing, product/service and support initiative, sponsorship of networking groups, national discount purchasing programs, quality assurance programs, advertising etc.?

-Contact franchisees who left the system to find out why they left and how the franchiser handled their departure? Did the franchiser help in the sale? Was it a dispute? How was it resolved?

- Contact these organizations for more information on franchise regulations, statistics, and trends:

-International Franchise Association, Washington, DC. Trade association for franchising.

-Department of Commerce, Washington, DC. Publishes statistical information on franchisers and franchisees.

-Federal Trade Commission (FTC), Washington, D.C. Provides information about franchise rules.

-The American Business Opportunity Institute, Inc., Bethesda, MD. Provides a national clearinghouse service for business and franchise opportunities, investments, 
regulations, and publications.

-Surf the Internet for franchise information.

\section{How to Select a Franchise Concept That's Right for You?}

If you decide that franchising is right for you, one of your first decisions should be to select a business concept that you will be comfortable with and that will offer you the best chance of success. ${ }^{6}$ Factors to considered are described below.

\section{Type of Work}

To be successful in business, you must enjoy working in the business. Pick a franchise that you are excited about going to work daily.

\section{Specialized Training and/or Education}

Some types of franchises require specialized training or education that cannot be provided in a few weeks. You should probably avoid such franchises if you do not have the specialized training or do not have the time to devote to the training.

\section{Number of Hours/Days of Operations}

Many businesses require that the facility be open late in the evening and/or on weekends (retail). If you want close-to-normal business hour operations, choose a franchise that provides them.

\section{Number of Employees}

Labor-intensive businesses (e.g., fast food) require many human resources issues ranging from hiring, retaining and training dependable help, complying with government requirements regarding insurance, benefits, etc. Many of these issues can be minimized by selecting a business that can be effectively operated by family members with the assistance of part-time help. Sometimes, this has both advantages and disadvantages. As the business grows, obviously the issues change.

\section{Capital Requirements for Start-Up}

The most common reason for business failure is under capitalization. The amount of capital required for start-up and the working capital were insufficient. Be certain to select a business that is appropriate for the capital you have available, which should include working capital to cover a six-month to one-year start-up period as well as capital required for equipment, supplies, inventory, consultation, and labor. Do not overextend yourself or incur so much debt that you will not be able to survive through the start-up phase.

\section{Susceptibility to Economic or Seasonal Fluctuations}

A business that provides basic products or services which customers will require in good or bad economic times offers leverage against economic fluctuations and often, even seasonal fluctuations. High-ticket items such as autos, luxury items, and travel are often curtailed during economic slowdowns, while food, healthcare, postal, and repair services tend not to be.

\section{Product v. Service Business Orientation}

Service franchises (e.g., education, telemarketing, postal services, quick oil change) are popular today as the economy shifts more to a service orientation.

\section{Family Involvement}

A growing number of franchisees combine their work and personal lives. Forty-two percent of franchises are purchased jointly by married couples. For some families, franchising may be very appropriate. ${ }^{7}$

\section{Existing Support, Infrastructure, and Name Recognition}

Buying into a new franchise system can be a terrific opportunity to get in on the ground floor. However, some new franchises do not yet have the marketing name recognition, nor do they have all of the support, training, and systems in place. Be extra careful when considering a new franchise. 
My wife and I educated ourselves about franchising and investigated more than twentyfive different franchise concepts. We made a list of franchise selection criteria that we used in choosing a franchise. The criteria were based on previous work experiences, our likes, our competencies, capital requirements, and other considerations. We identified:

- High-value added service-oriented business. We were interested in taking advantage of the high-growth service sector.

- Minimum capital investment. We wanted to minimize our capital investments and established a range of $\$ 100$ to $\$ 125 \mathrm{~K}$.

- Business hours. We wanted to invest in a business that had close-to-normal business hour operations while minimizing late nights and weekend work.

- Pre-tax profit margin minimum. We only looked at businesses with a 20 percent minimum pretax margin and a minimum annual growth rate measured in gross sales of 25 to 35 percent per year for the first three to five years.

- Home office/small business support related. In the early stages of home-based or small businesses, these companies outsourced many office, communications, and related support services. We were comfortable in this area and visualized it as having high growth potential.

- Number one franchiser in chosen area with national name recognition. We conducted a competitive analysis of the leading nationally recognized postal, business, and communications services providers (e.g., U.S. Post Office, Mailboxes, Etc., PAK Mail, Packaging Plus, Postal Annex, and others). Aside form the U.S. Post Office, Mailboxes, Etc. came out on top in several categories (e.g., largest number of stores, longest open, higher than average growth and profitability per store, excellent training programs, strong brand and name recognition). While their systems were inferior to other franchises at the time, they were undergoing major revisions.
- Territory exclusivity and protection. Most franchisers provide some sort of territory exclusivity determined by such factors as geography and /or population density.

- High resale value. The resale value of a business is determined by several factors, most of which are affected by how you grow and manage the business and its revenues, expenses, and profitability. In addition, the franchiser can influence the resale value by maintaining excellent marketing, brand recognition, finance, quality, communications and support programs, and minimizing turnovers and failures.

- Buy an existing franchise or develop a new one. We found that established franchises were generally more expensive and we were willing to take on the risks and challenges of starting a new business in a new location for a lower cost.

Once we selected a franchiser, we had to sell ourselves to the franchiser in terms of start-up funding, commitment, and abilities. Remember that the franchise system is designed to improve the odds of success by carefully screening, selecting, and training motivated individuals.

\section{What to Do Once You Have Selected a Franchise}

Once you have selected a franchise, reviewed the UFOC and related documents with your lawyer, and accountant, and put together a preliminary business plan with financials, you are ready to move ahead.

Mailboxes, Etc., the franchise we selected, is based on a three-tier structure. The first tier is the corporate franchiser, Mailboxes, Etc. The second tier is known as an "area franchisee." The area franchisee owns (buys it from the franchiser) an area and is responsible for developing and supporting it on behalf of the franchiser. The area franchisee is responsible for identifying new locations, selling franchises, conducting in-store training, and providing local or regional support. The third tier is the individual franchisee, who represents the revenue base of the franchiser. The steps we followed once we selected Mailboxes, Etc. included: 
-

- Arranged for financing through private sources.

- Selected a location. This is the most critical decision you will make in a retail franchise The site selected must have significant traffic, be visible from the major roads, and have excellent parking facilities. Mailboxes, Etc. assisted us in the site selection by providing reports on population demographics and statistics, as well as competitors' locations. Once you have located the ideal site, talk to other storeowners about traffic, the landlord, facilities, and lease options.

- Signed a lease. We signed a five-year lease with annual renewal options after the first two years to give us flexibility.

- Attended training. Mailboxes, Etc. provided a two-week, mandatory training program which is paid for by the franchisee. The program was thorough and intense. It reviewed all aspects of the business. In addition to the formal training program, we participated in a one-week, on-the-job orientation in an existing franchise. This was extremely useful and informative.

- Designed Store and Hired Contractor. Part of the training program was devoted to laying out the store design and determining such things as counter and merchandise space. Once the layout was completed, corporate furnished the blueprints to build our store. We hired a contractor recommended by other franchisees in our area.

- Developed marketing and promotion plans and programs. We established a computer database, completed a direct mail campaign, advertised our grand opening in the local newspapers, and conducted a door-to-door flyer campaign of over 1,000 prospects.

\section{Do's and Don'ts of Establishing Your Own Business Through Franchising}

Once you have decided to establish your own business through franchising, there are a number of do's and don'ts to consider.
Do's

- Do your homework. Finding the right franchise requires a lot of hard work. You should conduct research; interview franchisers, franchisees, and other professionals; and evaluate complex legal documents.

- Develop a pragmatic business plan. Construct a three-year business plan with pro-forma financials, including cash flow statements. It is probably a good idea to develop three plan scenarios: optimistic, normal (or expected), and pessimistic.

- Develop an actionable and flexible marketing and sales plan. Establish annual and seasonal marketing programs to promote the business and create customer awareness and loyalty. Focus on customer acquisition and retention strategies, including database marketing, (one to one) frequent user discount programs, and special promotions. Be prepared to install marketing program measurement systems to assess results and change promotion and marketing programs and budgets. Where possible, incorporate market segmentation principles to better target and position.

- Know your costs. Establish and maintain a tight cost control system so that you can track the costs of and profitability of all products and services. This will help you manage your business more effectively and profitably.

- Provide outstanding, courteous customer service and clean premises. In a retail service business, providing excellent and reliable customer service and a clean environment is critical to the success and continual growth of the business. You should resolve all complaints quickly and fairly. You should minimize "wait time" for servicing customers. Get to know your customers, their businesses, and their special needs whenever possible.

- Develop a contingency plan if things do not work out. If the franchise does not work out, you should develop a contingency plan to minimize your losses by selling, relocating, or dissolving the business. 


\section{Don'ts}

- Don't get in over your head financially or operationally. You must be realistic about how much you can afford on start-up and working capital, which should include debt payments. In addition, you should be comfortable in managing the business and not be overwhelmed by it.

- Don't be penny-wise and pound-foolish. If you are going to use the professional services of a lawyer, accountant, or other professionals, use the best your money can buy. Their advice can save you a lot of headaches down the road.

- Don't assume franchising is easy. Owning and managing your own business is one of the most demanding ways of earning a living. Most new franchisees find that there is a substantial learning curve involved (e.g., six months to one year) before they are comfortable. Clearly, this is very much a function of the franchisee and the complexity of the franchise. Also, be prepared to work harder and longer than you ever have. You must consistently be proactive if you want the franchise to grow and prosper.

- Don't get discouraged when business/competition gets tough. Most businesses tend to be cyclical, with good and bad periods. If you encounter a slowdown and you cannot think of ways to change the downturn, call for help from other franchisees, the franchiser, and outside experts. You should carefully and deliberately examine all functions, processes, and strategies and, where appropriate, reengineer them.

\section{How to Sell a Franchise}

After five years of consistent growth and hard work, we decided to sell our franchise. We contacted the franchiser to determine what the franchise pricing guidelines were. We also talked to franchisees who recently sold their businesses. We learned that the pricing guidelines for a business were based on various criteria which ranged from multiples of net sales to multiples of pretax net income. We set a price based on a multiple of pre-tax net income plus the value of existing merchandise inventory plus goodwill. Some of the selling strategies we used are described below.

- We established a fair selling price and added 20 percent to it to allow for bargaining leverage and potential sales commissions. We also established a minimum price below which we would not sell.

- We listed the business with both the franchiser and independent brokers on a nonexclusive basis. We prepared a "selling" information packet (e.g., audited financial statements, business plan, marketing plan) for use by prospective buyers. Over a four-month period, we successfully sold the business to a buyer who was introduced to us by the franchiser.

- We used our lawyer to draw up the selling contract. In addition, we had to go through a selling audit by the franchiser to assure that we had accounted for and paid all of our royalty and lease fees. We leased certain equipment and systems from the franchiser.

- Many sellers of small businesses have to partially finance the sale of their business over a five-year or longer time period. We chose not to finance and were able to get our full sales price up front. The franchiser provided financing to the buyer.

- We initiated the transfer of our lease to the new owner with the landlord.

\section{Conclusions}

Starting any type of business is risky, even under the best economic conditions. To cut the risks and facilitate the transition to your own business, an increasing number of entrepreneurs and corporate converts are buying franchises. Instead of starting a business from scratch, they buy a blend of individuality (own business) with the brand recognition, training, and established infrastructure of a franchiser. Generally, there are more expenses involved in franchising than in starting your own business.

Franchisees, like all business owners, can improve performance by carefully analyzing their competitors and customers. The better franchisers 
are also proactively improving their relationships with the franchisees by listening more and acting on field recommendations for more effective marketing, training, and support programs. ${ }^{8}$

Despite the hard work and long hours, we found franchising to be a positive experience. We gained the confidence and knowledge of managing our own business. When the price and time were right, we sold the franchise.

As to the future of franchising and according to studies published by Arthur Anderson, the International Franchise Associations, and the Gallup organization, franchising's potential is almost unlimited. Franchising is also growing internationally, primarily through the efforts of major U.S. firms such as McDonalds, Pizza Hut, Wendy's, and Mailboxes, Etc. According to John Naisbitt, author of Megatrends, "Franchising is the most successful marketing concept ever created."

\section{Endnotes}

1. Department of Commerce, Franchise Opportunity Handbook, Washington, DC: 1994.

2. Franchising in The U.S. Service Sector: How Periasive, How Successful? Market Data Enterprises, Inc. Study, Valley Stream, NY: January 1995.

3. Caffey, Andrew, "A Closer Look At Franchising," Entrepreneur, January 1996.

4. Ibid.

5. Page, Heather, "What It's Really Like to be a Franchisee," Entrepreneur, January 1966.

6. Mailboxes, Etc, How to Evaluate a Franchise Opportunity, San Diego, CA: 1989.

7. Fodt, Dan and Susan Mitchell, "Small Stores with Big Names," American Demographics, November 1992, p. 56.

8. McDermott, Kevin, "The Hard Facts about Franchising," DEB Reports, September-October 1993.8

9. Beresford, Lynn, "Franchise Explosion," Entrepreneur, January 1996.

\section{NEJE}

Gad Selig joined the College of Business at Sacred Heart University in 1995 as a full-time faculty member, teaching graduate and undergraduate courses and executive seminars in business strategy, marketing, technology, project management and leadership. Dr. Selig has thirty years of diversified domestic/international executive, management, and consulting experience with both Fortune 500 and smaller companies in the financial services, utility, information technology, telecommunications, manufacturing, and retail industries. His experience includes: marketing, sales, planning, operations, business development, mergers and acquisitions, general management, systems/network integration/out-sourcing, MIS/CIO telecommunications, the Internet, product development, training, and entrepreneurship.

Dr. Selig is also managing partner of Gad Selig \& Associates, Inc., a consulting, research, and training firm that focuses on strategy, technology, and marketing topics and workshops for large and small businesses. 